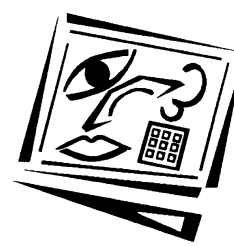

\title{
Lecturers' attitudes about the use of learning management systems in engineering education: A Swedish case study
}

\author{
Ramon Garrote and Tomas Pettersson \\ University College of Borås, Sweden
}

\begin{abstract}
The purpose of this study was to examine lecturers' attitudes towards learning management systems (LMS), with particular reference to identifying obstacles to increased use. At the University College of Borås, Sweden, 22 lecturers who had used WebCT during the previous 9 months were interviewed. The answers show that most of the lecturers, including those who only used minor parts of the LMS, believed that they could benefit from using a LMS in the future. The study did not support the hypothesis that fear of the complexity of the system or unwanted effects on education are important reasons for lecturers not to use the LMS. When lecturers decide individually to use tools in the LMS, the major concern is the initial amount of work compared with the expected benefits. Due to the benefits of a fully implemented LMS and the results of this study, it is recommended that institutions in higher education take actions to establish LMS as a standard tool, and support development of the lecturers' professional competence.
\end{abstract}

\section{Introduction}

Learning management systems (LMS) are computer programs that integrate functions for teaching, evaluation and administration of courses. Other terms sometimes used include VLE (virtual learning environment) (Dutton. Cheong \& Park, 2004; Seeger \& Åström, 2005) and the broader term ICT (information and communication technologies) (Bongalos et al., 2006; Dutton, Cheong \& Park, 2004) which may include LMS as a component. Commercially available LMS have many features in common, including shared documents, discussion board, assessments, grade book and chat room (Britain \& Liber, 1999; Seeger \& Åström, 2005; Sigrén \& Holmqvist, 2005). Earlier research showed that the use of LMS is increasing in higher education, but many lecturers use only the parts or functions that replace older techniques for reproducing and distributing documents (Bongalos et al., 2006; Dutton, Cheong \& Park, 2004; Garrote, 2006). There is 
also strong evidence to suggest that most teachers, even if they only use a few functions in an LMS, are optimistic about the potential benefits (Bongalos et al., 2006; Wan Ng \& Gunstone, 2003).

In Sweden there are strong expectations and political pressures on the education system to increase the use of information and communications technologies (ICT) to enhance performance and facilitate flexibility in education (Regeringen, 1996). In 1998 the Swedish government presented a report to the parliament with a plan for the use of information technology (IT) in schools (Regeringen, 1998). The plan concerned preschool to high school levels, and there was an explicit ambition to increase the use of IT, even if no conclusive evidence was available to indicate strong positive effects on education (Pedersen \& Skolverket, 1998). Sweden is just one of many examples, as similar expectations have appeared all over the world. (Wan Ng \& Gunstone, 2003). One well known example is the Dearing report in Great Britain:

We recommend that all institutions should, over the medium term, review the changing role of staff as a result of Communications and Information Technology, and ensure that staff and students receive appropriate training and support to enable them to realise its full potential. (List of recommendations, in Education, 1997).

\section{The development of LMS}

A modern, fully developed LMS has to meet a number of expectations from educational institutions and other customers. An indication of the demands on available tools, technical reliability and compatibility with other systems may be found in public contracts for procurement of LMS by educational institutions. (Sigrén \& Holmqvist, 2005). Changes in LMS capabilities may occur in the future, due to requests from customers for additional features and other causes.

It is difficult to identify a particular program as the first LMS, as these are 'toolbox' programs for teaching, evaluation and course administration, with more and more features added over time. By 1995 some universities in the USA had started to connect the programs used in education with the Internet and there were high expectations about the benefits of that integration (Newberg, Rouse \& Kruper, 1994). In 1999 the following definition of a VLE that also fits the term LMS was given:

\footnotetext{
Virtual Learning Environments (VLEs) are learning management software systems that synthesise the functionality of computer-mediated communications software (e-mail, bulletin boards, newsgroups etc) and online methods of delivering course materials (e.g. the WWW) (Britain \& Liber, 1999).
} 
From about 2000 there have been many reports of investigations and descriptions of education projects using LMS as tools for developing new methods in teaching (Björck, 2004), flexible methods for off campus education and e-learning (Gisselberg, 2002), and facilitation for disabled students and problem based learning (Björck et al., 2003).

\section{Questions}

Questions concerning the application of LMS were put forward by Dutton, Cheong and Park (2004):

- What is the actual experience of implementing VLEs?

- Which main social, cultural, psychological, economic, technical and other factors facilitate or constrain the uses to which the VLE is put?

- To what degree does a VLE complement or replace traditional learning environments?

- What kinds of VLE based teaching and learning approaches are most effective?

- Which VLE capabilities lead to difficulties or are underused?

- How easily can a VLE be tailored to the needs of particular contexts, teachers, students, administrators, etc?

- Who in educational institutions are likely to be the winners and losers from the introduction of a VLE?

- What kinds of policies and resources are needed to make a VLE effective?

- What are the implications of the way a VLE can be used to reconfigure how faculty, administrators, students and others in an educational institution gain access to people, services, information and technologies? (Dutton, Cheong \& Park, 2004).

The above questions have been transformed into 26 questions below, which were used in the interviews with lecturers.

\section{Questionnaire used in the interviews}

(The interview is started with a short description of the aim of the study and a description of Learning Management System. A list with components should be available).

\section{Experiences with the LMS}

What part of a Learning Management System (LMS) have you used:

1. Pages (Organizer Page, Single Page, URL)

2. Course Content Tools (Syllabus, Content Module, Glossary, Image Database, Index)

3. Content Utilities (Search, Content Compiler, Resume Course, CD-ROM)

4. Communication Tools (Discussions, Mail, Chat, Whiteboard, Calender, Student Tips)

5. Evaluation \& Activity Tools (Quizzes/Surveys, Test, Assignments, Student Presentations, Student Homepages)

6. Student Tools (My Progress, My Grades, Language Selector) 
In questions 7-23 the answers were scored according to the following scale:

Agree in full $1-2-3-4-5$ Do not agree at all

Attitudes and expectations

LMS in general:

7. A LMS will be used by almost all lecturers within some years.

8. A LMS can increase the results of the students at the University College.

9. A LMS can facilitate the work of the lecturers to a large extent.

Your own use of a LMS:

10. You are going to use most of the parts of a LMS within some years.

11. You would like to get more education and support to be able to use a LMS to a full extent.

12. A LMS can be of great benefit in the courses you teach in.

Introduction of a LMS (WebCT) at the School of Engineering

The need for education at start/before start:

13. You obtained sufficient introduction to start with WebCT.

The need for support:

14. There is a good support if technical problems would arise with WebCT.

15. If you have any questions about the LMS at the school where you teach at the University College of Borås there is always a possibility to get support.

The climate at the School of Engineering:

16. There is a good discussion among the lecturers about how a LMS can be used.

17. The lecturers are encouraged to use a LMS by the school at the university college where they work.

Education and a LMS

How does a LMS change the role of the Lecturer:

18. A LMS has a great influence upon the education.

19. A LMS leads to changes in planning and implementation of courses.

20. A LMS contributes to the change of the content of the courses.

21 In the future a LMS will be a necessity for all lecturers.

How does a LMS influence students:

22. A LMS makes a great difference for students at the university College.

23. All students have to use a LMS in the future.

The answers to the three questions below can be recorded by key words.

What advantages can a LMS offer in education?

What problems can a LMS cause in education?

What is important to remember in the implementation of a LMS?

\section{The questionnaire}

The interview was structured with yes/no questions, multiple choice questions, and at the end of the interview, three open ended questions to obtain additional information, particularly about values and opinions of 
the interviewees (Merriam, 1994). The questions were presented and discussed in Swedish. Translations were made by the authors.

Questions 1-6 were yes/no questions concerning personal experiences with LMS. Questions 7-23 were multiple choice questions in the form of given statements to which the interviewees could respond. The answers were noted by the interviewer on a five-point scale ranging from "completely agree" to "do not agree at all". Thus it was possible to quantify the results and to test hypotheses (Merriam, 1994). The answers to questions 7-12 demonstrate opinions about LMS in education in the future, numbers 10-12 more specifically about the interviewee's own work. Questions 13-17 were intended to show how the lecturers' personal experiences and feelings, not to measure the availability of support or instruction. Number 13-15 show to what extent the interviewees felt that they had adequate help and support to start using LMS, and questions 16-17 were about institutional attitudes towards the LMS. The remaining multiple choice questions were intended to investigate lecturers' expectations about the impact of the LMS upon education. The interview was finished with three open ended questions.

\section{Scope and purpose}

This investigation concerns the use of LMS by lecturers at the School of Engineering at the University College of Borås, who have had opportunities to use WebCT since 1999. The focus of interest is the lecturer's feelings and attitudes about working with a LMS. It aims to provide useful information for people involved in the implementation of a LMS, as well as contribute to the knowledge of the use of educational technology in general. A specific hypothesis to test is whether lecturer hesitation about adopting new technology, due to fear of its complexity or fears of undesirable impacts on education, is a serious obstacle to full implementation of the LMS.

\section{Method}

Qualitative methods are often preferred when the aim is to get a deeper understanding of the problem and to describe its whole context within society (Holme, Solvang \& Nilsson, 1991). In this investigation interviews were used because its focus was to explain the pattern of use of LMS found earlier (Garrote, 2006), understand how the people experienced their situation, and to find common patterns within the group (Denscombe, 2000).

A test interview was performed with an observer present, after which the final questionnaire was determined and it was decided to rely on written notes during the interviews, without audio recordings. 


\section{Selection}

The investigation covered all lecturers in the School of Engineering at the University College of Borås, who conducted a course that was registered in $W e b C T$ during the first nine months of 2006. Collection of data from all members of that group was sought, to obtain the highest possible reliability (Flick, 2002). The population was mapped using a list of teachers in all courses given at the School of Engineering during the time frame and a list of the courses registered in the institution's WebCT LMS. Thus 23 lecturers were selected, approached personally and/or by mail, with 22 agreeing to an interview. One lecturer who declined to participate after a third personal contact was omitted from the investigation.

\section{Results}

\section{Most frequent response}

For questions 9, 11, 12, 16 and 23 one alternative received more than half of the responses, while for questions 8,14 and 22,16 of the 22 responses were on two adjacent alternatives, thus suggesting a common opinion for the entire group of interviewees (Denscombe, 2000).

\section{Subgroups}

The first six questions in the interview were intended to see what parts of a LMS the respondent had used. The tools in a LMS were divided into six kinds: Pages, URL, Course content tools, Content utilities, Communication tools, Evaluation and activity tools and Student tools (Garrote, 2006). The respondents were divided into three groups according to their experience of using LMS. The most experienced group, seven people, were lecturers who had used at least five of the six kinds of tools, the intermediate group, eight people, had used three or four kinds of tools, and the last group, seven people, had used at most two kinds of tools. The differences between the three groups is shown in Figure 1, where the mean value of the responses is given for each group.

\section{Correlations}

Correlations between answers to questions 7-23 were calculated but the numbers were low, and in only three cases did the correlation coefficient exceed 0.6. Questions 9 and 20 have a correlation coefficient of 0.74; questions 15 and 21 had -0.68 and questions 20 and 22 had a correlation coefficient of -0.63 . 


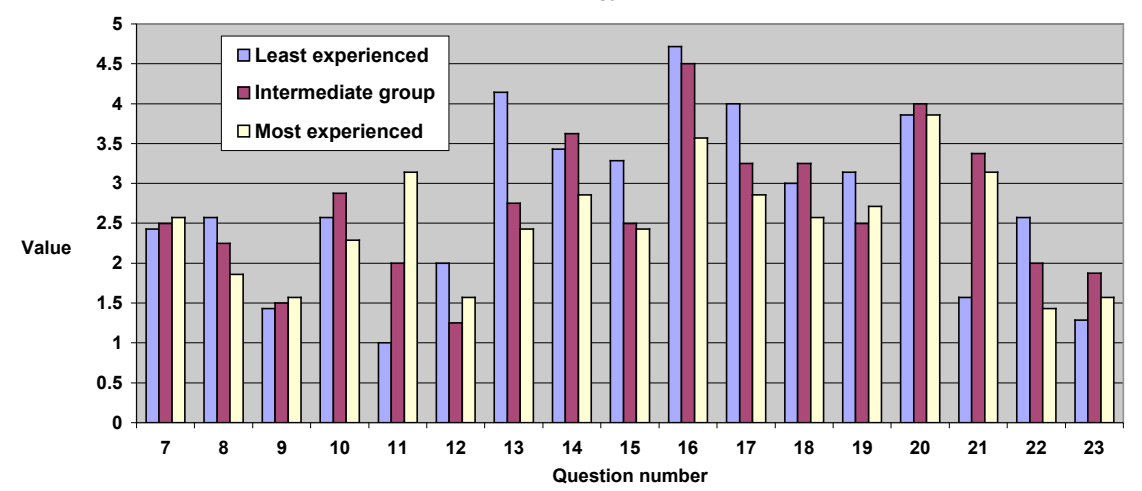

Figure 1: Mean values of the responses of the three subgroups.

Value: 1 = completely agree, $5=$ don't agree at all.

\section{Responses to questions 7-23}

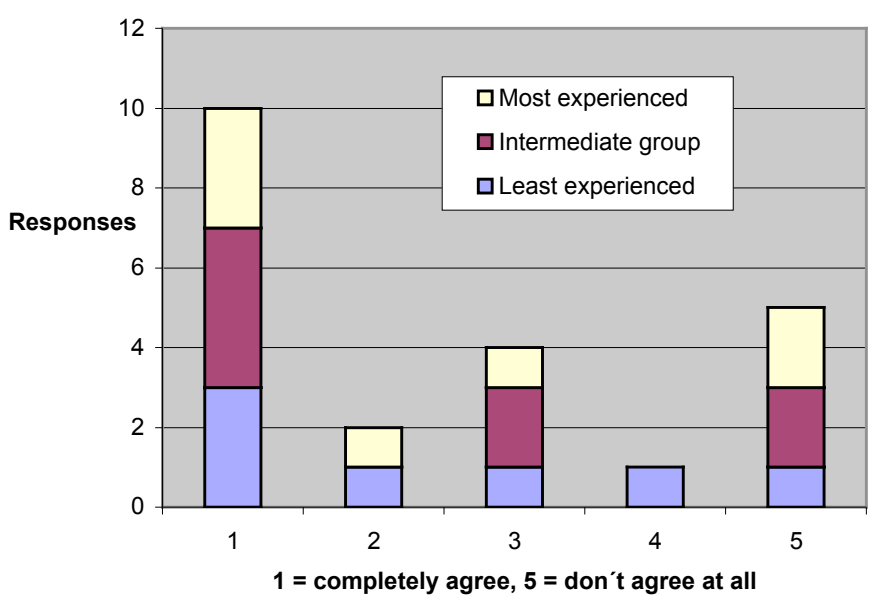

Figure 2: Responses to question 7: A LMS will be used by most lecturers within a few years.

There is no common opinion about question 7 , in all three subgroups there are people who agree and who disagree. 


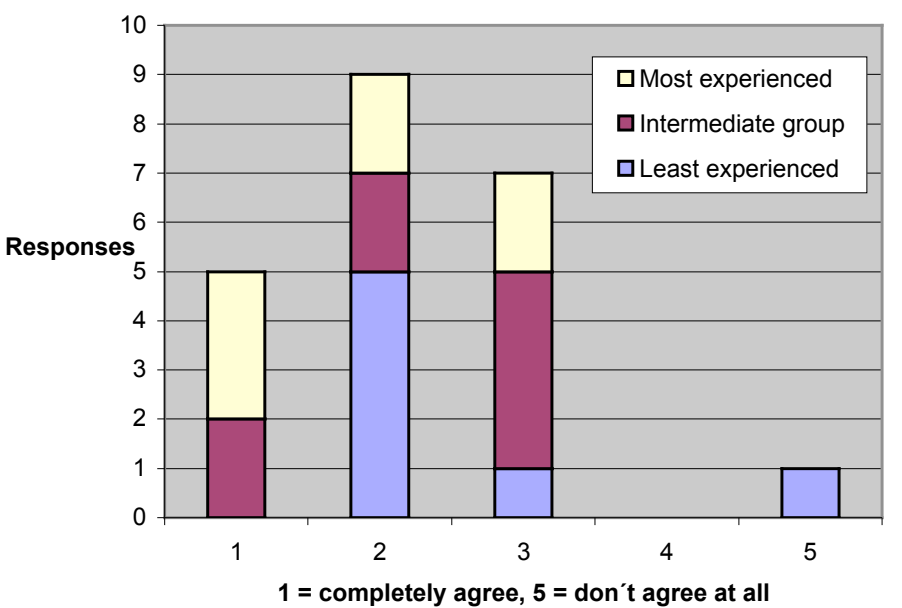

Figure 3: Responses to question 8: A LMS can increase study performance Lecturers are not convinced that a LMS can enhance study performance.

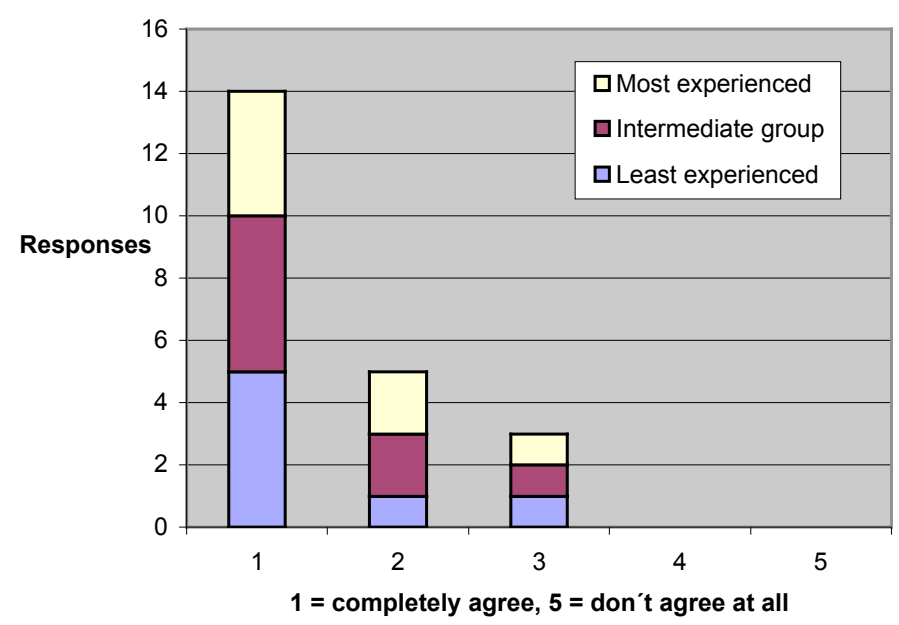

Figure 4: Responses to question 9: A LMS can facilitate the lecturer's work considerably.

It is a common view that a LMS can facilitate the lecturers' work considerably. 


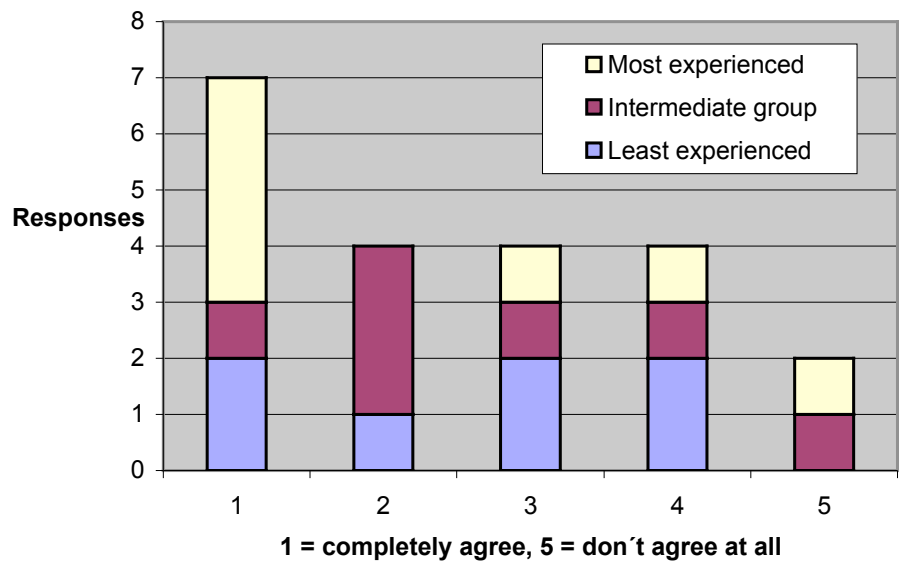

Figure 5: Responses to question 10: You will use most parts of a LMS within the next few years.

There is a wide range of expectations; note that the most experienced group includes those lecturers who already use most parts of a LMS. The expression "parts" refers to the distribution of tools into groups used in an earlier investigation (Garrote, 2006), that were used in question 1-6.

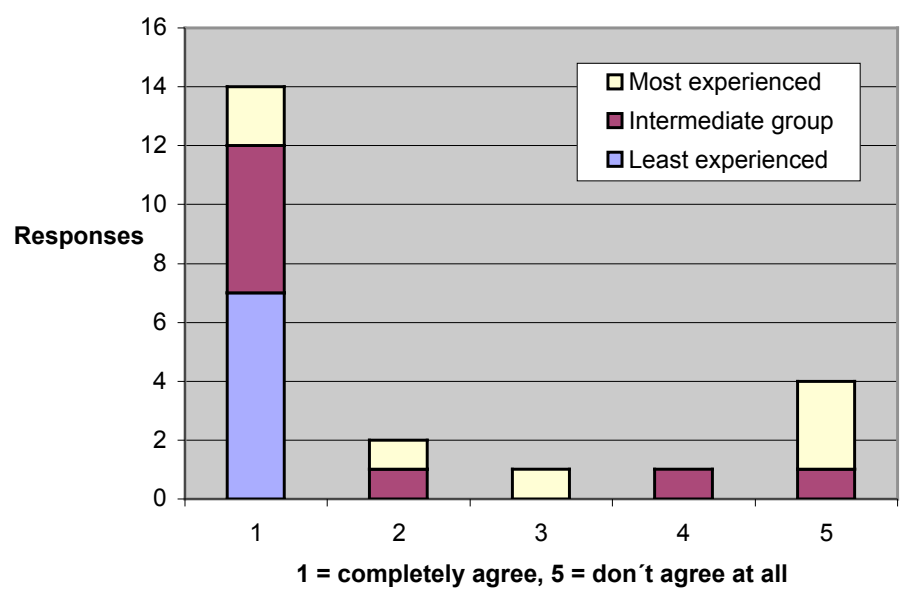

Figure 6: Responses to question number 11: You want more education and support to be able to use all components of a LMS.

Most of the lecturers want more education and support, notably those in the least experienced group. 


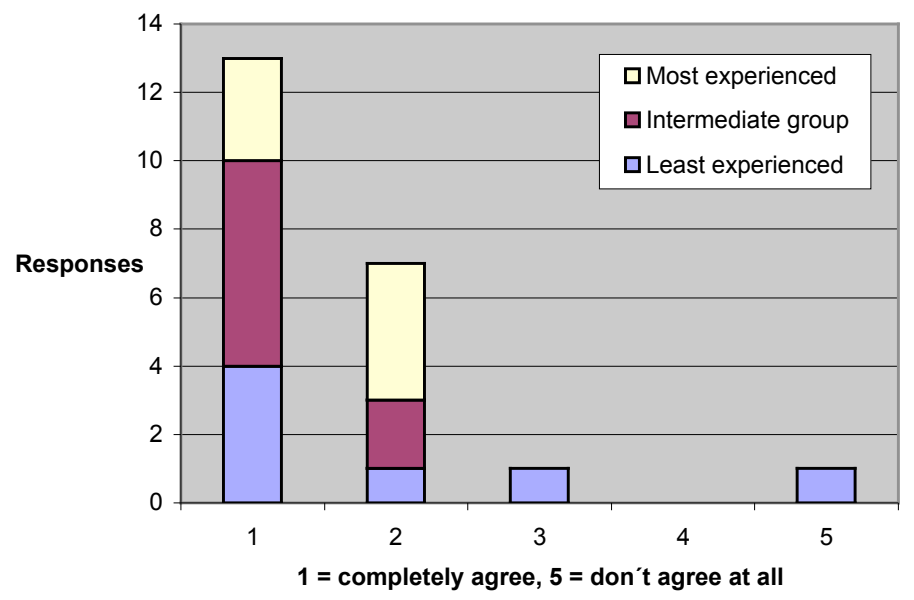

Figure 7: Responses to question 12: A LMS can be a great help in the courses you teach.

20 out of 22 lecturers agree that a LMS could be a great help in their courses.

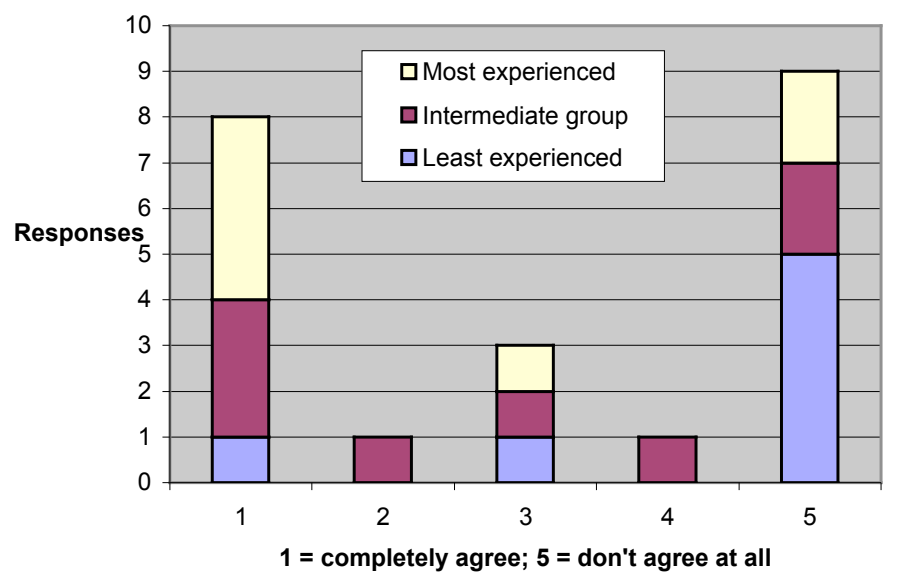

Figure 8: Responses to question number 13: You had a sufficient introduction to start using WebCT.

Many lecturers say they didn't get a sufficient introduction, meaning they either had an insufficient introduction or that they didn't get any introduction. There is a large difference between the three groups; the most experienced users are more satisfied with the introduction they received. 


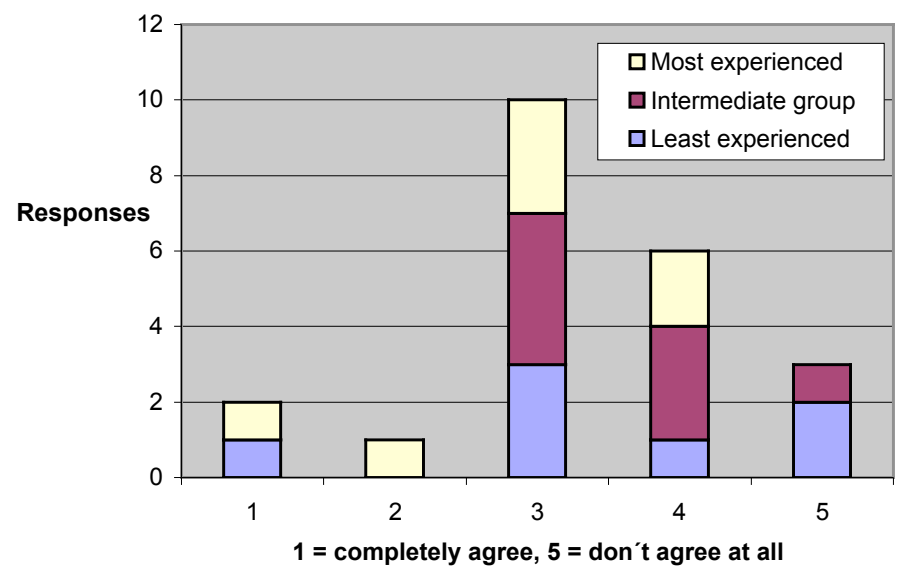

Figure 9: Responses to question number 14: There is good help available if there is a problem with WebCT.

Most of the lecturers are uncertain whether they can get help if there is a problem. However, no respondent had personally experienced this as a problem.

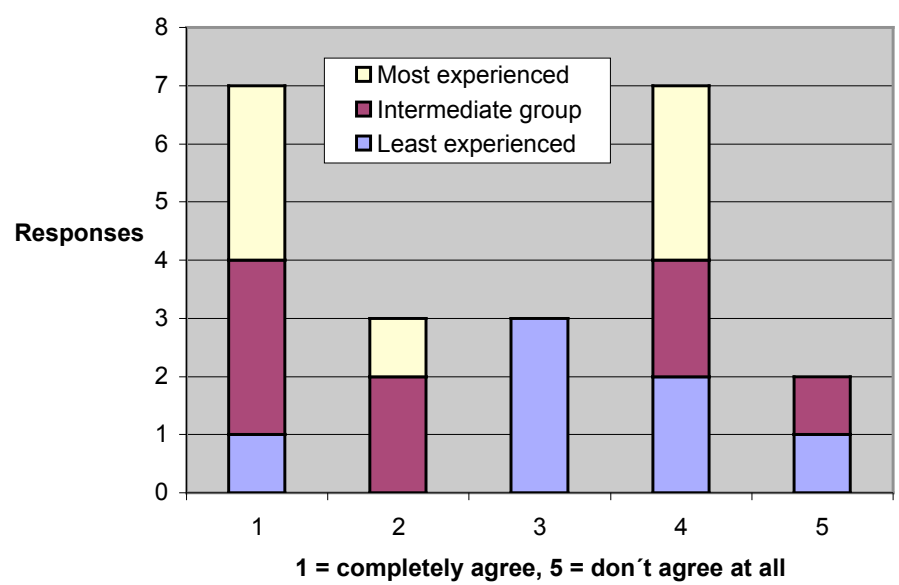

Figure 10: Responses to question 15: If you have questions about the LMS you can always get help.

There is a wide spread in the responses; it seems that most of the lecturers rely on informal contacts within the institution for help. 


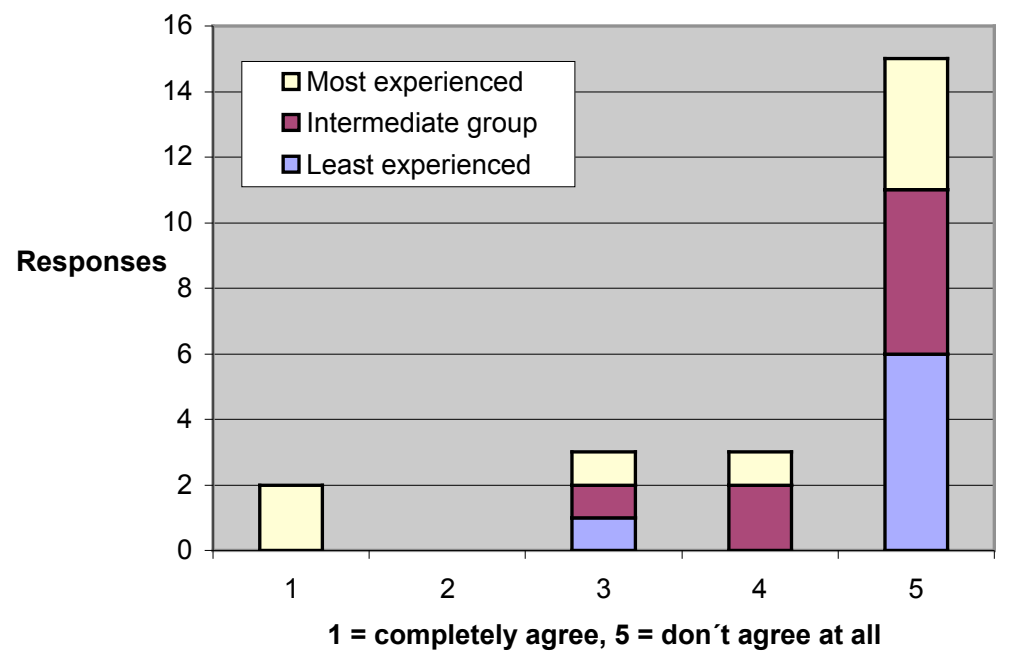

Figure 11: Responses to question 16: There is a good discussion going on among the lecturers on how to use the LMS.

Only a few of the most experienced users think there is a good discussion going on.

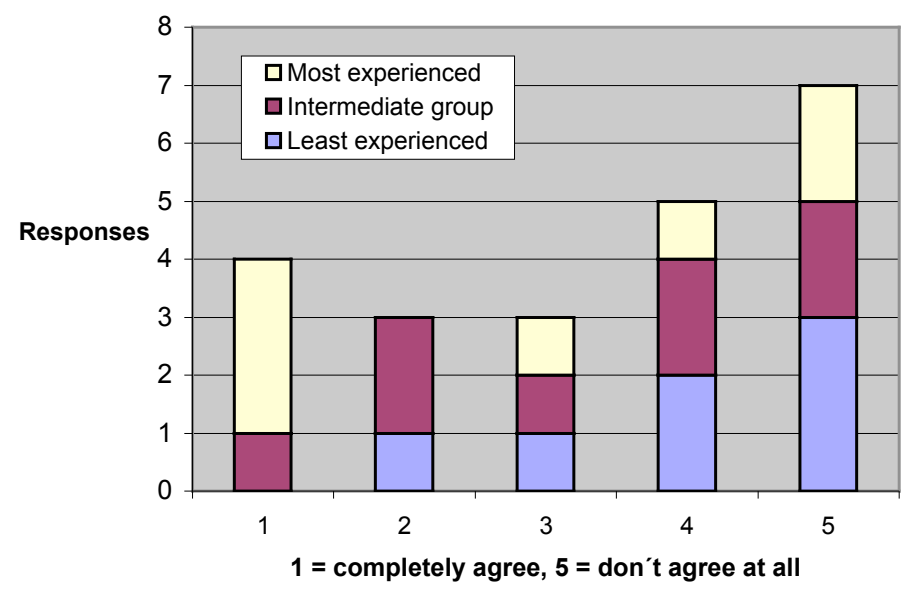

Figure 12: Responses to question 17: Within the institution lecturers are encouraged to use LMS.

Opinions vary widely; interesting to note is that the least experienced users do not seem to feel any particular pressure to increase their use of LMS. 


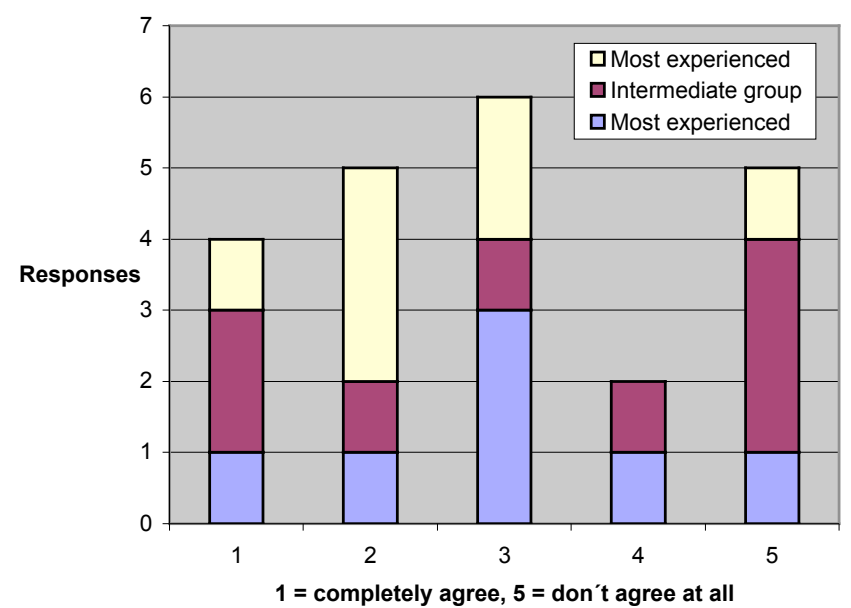

Figure 13: Responses to question 18: LMS have a great impact on the teaching process.

Lecturers have differing opinions about this, irrespective of their level of experience. Many courses are given off campus and in those courses a LMS may significantly influence the teaching; the impact a LMS may have probably depends also on the subject.

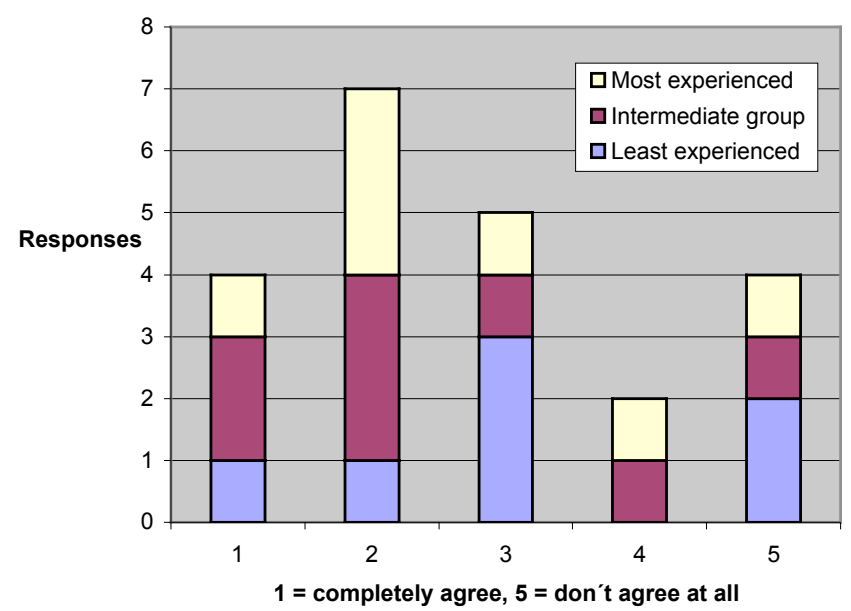

Figure 14: Responses to question 19: LMS changes the planning and execution of courses.

Lecturers do not agree on whether a LMS makes a difference in the planning and execution of courses. Many courses are given off campus and 
in those courses a LMS may significantly influence the entire course design. How much impact a LMS have on course design probably depends on the subject as well.

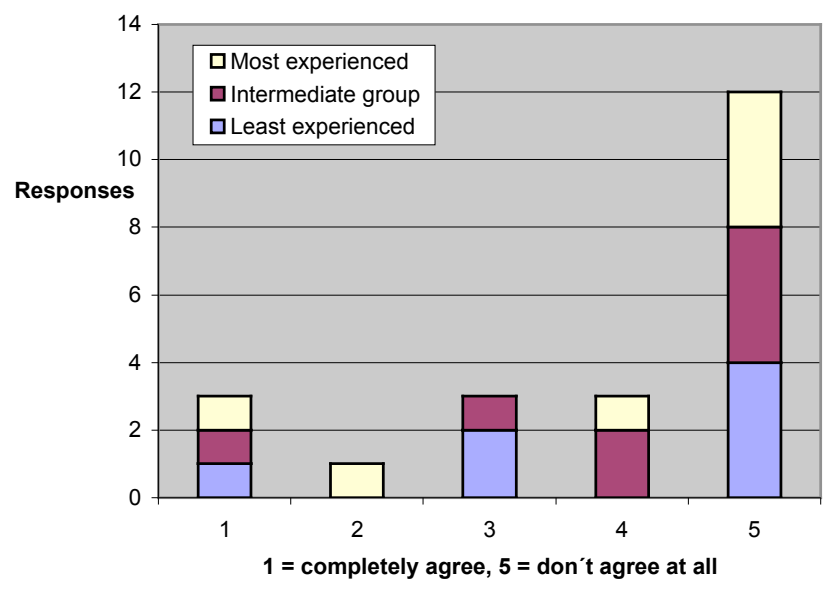

Figure 15: Responses to question number 20:

A LMS contributes to change of course content.

The dominant opinion is that LMS do not affect the course content. There is a negative correlation with question 9, indicating that those who believe a LMS can be of great help to lecturers don't believe it will have an effect on course content.

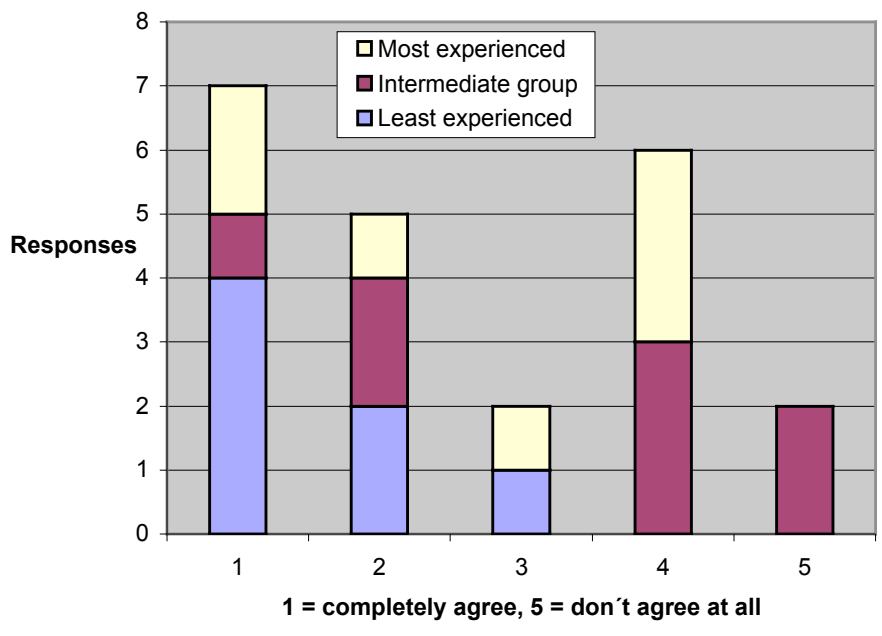

Figure 16: Responses to question 21: All lecturers will have to use LMS in the future. 
There is divided opinion, with the least experienced users tending to believe it will be necessary for all lecturers to use a LMS in the future. Lecturers may have to use LMS on two different grounds. It could develop into an inadmissible tool or it could be that the use of a LMS becomes mandatory for lecturers within the institution.

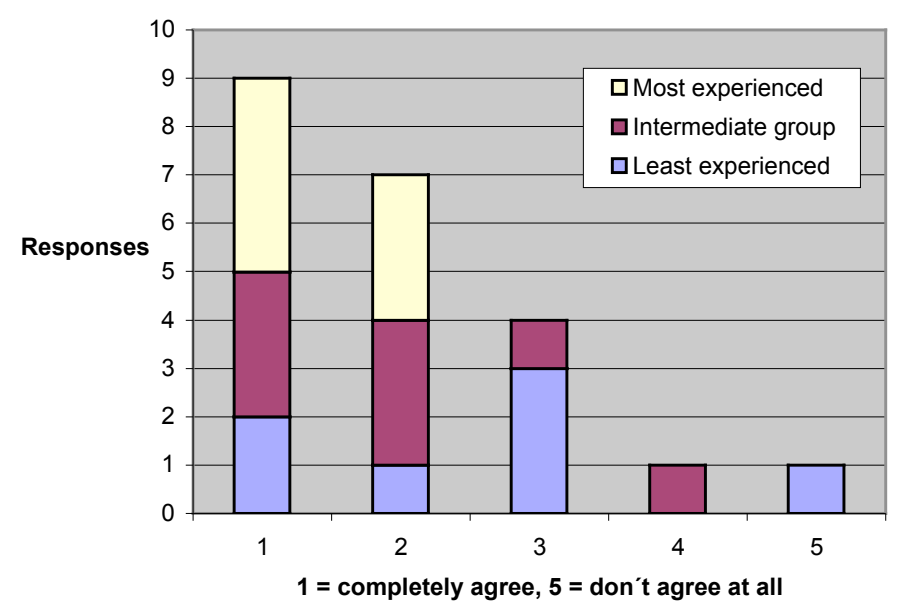

Figure 17: Responses to question 22: A LMS makes a great difference to students.

Most of the lecturers agree that LMS makes a difference to students, but it is not clear if that difference can be considered a major one.

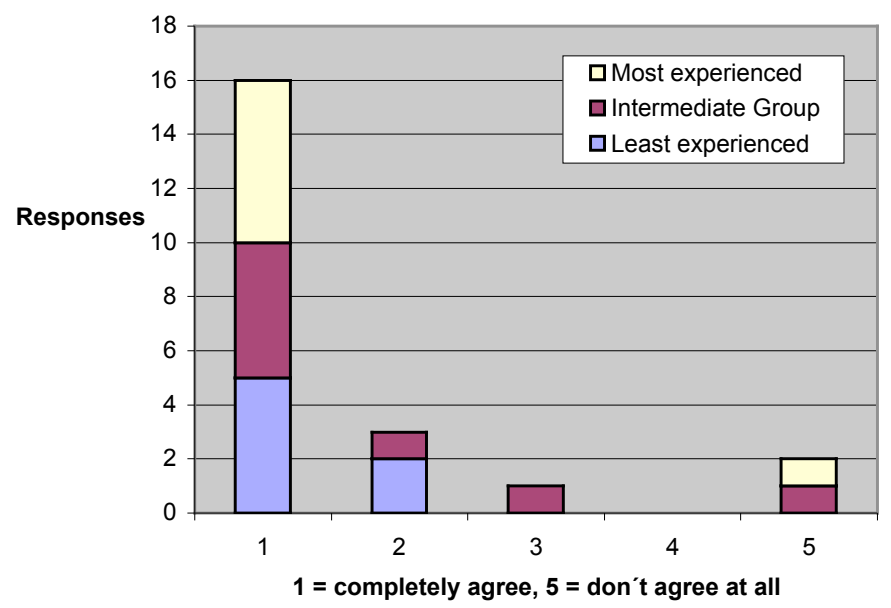

Figure 18: Responses to question 23: Do You think all students will have to use a LMS in the future. 
The common opinion is that all students will have to use a LMS in the future.

\section{Responses to questions 24-26}

Question 24: What are the benefits of a LMS in education?

All the interviewees saw the convenient distribution of documents from lecturers to students as the biggest advantage with a LMS. Students get access to all kinds of documents, texts as well as pictures from lectures and PowerPoint presentations. For the lecturers it is very convenient to have all documents for each course in the same place, it facilitates both planning and the teaching process.

Question 25: What problems can a LMS cause in education?

Students may be less motivated to attend lectures when all material is available online, that may lead to lower study performance, particularly among weaker students. Students who are not used to computers may be at a disadvantage. The may be less personal contact between lecturers and students.

Question 26: What is important to think about when implementing a LMS?

The system must be user friendly and reliable. The lecturers must get proper familiarisation and it is very important to have people close to the daily work environment to help when there are problems and to give advice when new courses are starting up. To motivate lecturers it is important to have good examples and to concentrate on the system's basic features. In particular, less experienced users point out that it is important to adapt to the local needs and focus on the features most likely to lessen lecturers' workloads.

\section{Interpretation of the answers}

\section{The lecturers}

Almost all lecturers used the institution's LMS to distribute material that would otherwise have been handed out as paper copies. Approximately half of the lecturers have used communication tools, such as email, discussion forums or chat, and almost half of them have used tools that allow students to take tests and hand in assignments. The remaining tools are infrequently used, except by a small group of lecturers. Hence a large part of the lecturers at the School of Engineering fall into the group of users Dutton, Cheong and Park (2004) describe as type 1:

...eClass was used most often as an alternative to the copy machine, by providing students with online access to assignments, readings, lecture notes and other class documents. This was typified by Professor 1, who felt 
the system simplified his work and enabled him to concentrate more on his research by freeing the time he previously spent using the copier. (Dutton, Cheong \& Park, 2004).

There is a consensus among the lecturers that a LMS can help their work considerably, even if it is used only to distribute documents. Other tools for communication between students and lecturers or between students are viewed as beneficial tools in teaching and learning, but not time saving for the lecturers. Tools for evaluation and activity are seen as potentially beneficial but also as potentially time consuming for the lecturers.

The common view is that LMS will be used more in the future, but the lecturers do not believe it will have a substantial impact on the course content or the teaching process.

\section{Lecturers and LMS}

A comparison of the expectations the lecturers have about LMS and the tools they actually use shows that the average lecturer uses the tools he or she believes will make their work easier and save time, if it doesn't take too much of an effort to get started. That means they choose not to use the tools that may have a large impact on education and tend to use the tools that merely facilitate a traditional teaching process.

There is an apparent contradiction between the lecturer's high expectations about a LMS as a help in their work, and their reluctance to use many of the available tools, though that may be explained as a matter of perspective. When lecturers ponder the questions of future use of LMS, they tend to take for granted a long term development, with increasing use of LMS, software development and increasing computer literacy among students and lecturers, and they look at the potential gains for students, institutions and the professoriate. When deciding what tools to use in the courses they are responsible for, with the students they are teaching in the near future, the most important consideration is their estimate of the time and effort they need for a new tool as compared to their expected gains.

The most important restricting factor in the use of LMS is the lecturer's lack of motivation to spend the time and effort necessary to use a wider range of the available tools, not any doubts about their ability to work with the systems, given adequate education and support. There is also very little doubt about the positive long term effects of LMS on education.

\section{LMS and the teaching process}

The tools in a LMS that most lecturers choose are those that replace existing technology, such as copying machine, overhead projector and email, 
without changing the teaching process or course content. The common opinion among the lecturers is that the use of LMS may change teaching, planning and course administration, but will not lead to any significant changes in course content.

\section{The introduction of a LMS}

If an institution wants lecturers to use the LMS and fully exploit its possibilities, it is necessary to have a plan for introduction, support and evaluation. An investigation of the impact of ICT in higher education sums up:

In order to be successful, indeed, the commitment of some dedicated individuals will not suffice; the institution itself must make a commitment (i.e. for support, resources and personnel) and has to develop a targeted implementation strategy.(Collis \& van der Wende, 2002)

The School of Engineering experience shows that the institution has relied mostly on the lecturers' initiative to learn and implement the LMS given, WebCT. Because of that, many lecturers only use the system to distribute documents to students. Nevertheless, many lecturers express an interest to learn the system, a result similar to other investigations:

Interestingly, despite some doubts as to the place of an LMS in their instructional platform, teachers have generally expressed openness, excitement and motivation to learn (Bongalos et al., 2006).

Some concerns were expressed in the interviews that students who do not have access to a computer at home, or lack sufficient computer literacy, will have problems and may demand extra effort on the lecturer's part. Supposedly that problem will decrease as the use of LMS is established as a norm, making it mandatory for students to use the systems from the beginning of their education.

\section{Discussion}

A starting point for this investigation was the result from earlier research that LMS in higher education was used primarily to facilitate the teachers' work by replacing earlier methods of document distribution (Bongalos et al., 2006; Dutton, Cheong \& Park, 2004; Garrote, 2006). It is no surprise, being a limitation in the use of IT expressed by others:

As such, Internet, intranet and extranet applications are often approached merely as alternative ways of distributing information rather than as involving new forms of action and interaction... (Slevin, 2000:121)

By performing this investigation at an institution with about 60 lecturers and 1400 students, it was possible to interview all lecturers who had had 
the opportunity to use the institution's WebCT within the previous nine month period, irrespective of the extent to which they actually used it. In particular, it means that teachers who choose not to use an available LMS were included; a group probably under-represented in several earlier investigations (Denscombe, 2000:29). Due to that, it is reasonable to assume that the results of this investigation are more representative for many institutions of higher education than some earlier studies.

Many problems associated with the implementation of LMS are normal when changing work processes in institutions, major changes in processes may take a conscious effort, "Process innovation initiatives are inherently distinct from business as usual" (Davenport, 1993:23). So far, most educational institutions have relied on successive increases in the use of IT (Collis \& van der Wende, 2002:7). A problem when implementing a LMS in an educational institution and making changes in work processes is that traditionally lecturers are individually responsible for the detailed planning and execution of courses. This means that some lecturers may lack motivation to undertake the necessary work to start using new tools, even if there are great benefits for the institution, other staff and students.

An important result from this investigation is that even those teachers who choose not to use most of the tools available in a LMS believe that the systems have considerable potential to make teachers' work easier.

In many countries there is a considerable political pressure to increase the use of IT in education, one example from Great Britain is the Dearing Report (National Committee of Inquiry into Higher Education):

We recommend that all institutions should, over the medium term, review
the changing role of staff as a result of Communications and Information
Technology, and ensure that staff and students receive appropriate training
and support to enable them to realise its full potential (Education, 1997: List
of recommendations, Ch 8:9).

In Sweden a government report stated that the use of IT should be increased in higher education to improve quality (Regeringen, 1996:34), and in 1998 a national program for IT in the school system was presented (Regeringen, 1998). The Government strategy in Sweden in 1998 to increase the use of IT in education, even if there was no conclusive evidence available at that time for strong positive effects, seems to have been formed in the middle of the 1990s when the importance and benefits of IT may have been exaggerated. Thus the strategy formed in 1998 could be seen as an expression of a political vision and expectations about futures.

Another question could be: "Why are we still asking basic questions about the acceptance, use and benefits of learning management systems?" Here it 
seems that LMS are complicated systems that need a significant effort before the users can see the benefits of adoption. In Sweden there has been a period of about three years with processes of evaluation of the most adequate learning management systems for the higher education. When discussing acceptance of and possibilities for increasing the use of a LMS in a university of technology, a project group has found from some lecturers that they preferred to wait and see what sort of LMS their university will end up with. The impressions from this study are that the greatest benefits of LMS have been in distance education.

A modern LMS has to meet high expectations from educational institutions. Demands on availability of tools, technical reliability and compatibility with other systems are specified in public contracts for procurements of LMS by educational institutions (Sigrén \& Holmqvist, 2005). Clearly the systems are now reliable enough, so lecturers and students may use them without having to consider backup processes that otherwise can lessen the beneficial effects considerably. So the main remaining obstacles to establishing wider use of LMS are structural:

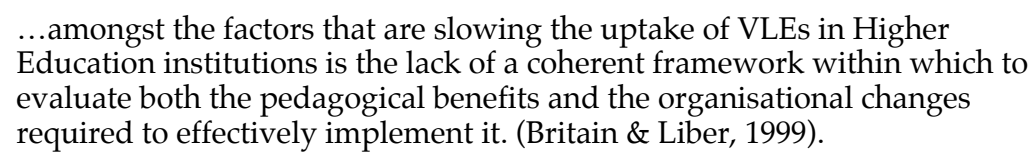

To increase the use of LMS the institutions need to develop strategies that include plans for procurement of systems, education and support. It is probably necessary to appoint a project manager (Craig \& Jassim, 1995) within the institution to make sure the plans are realised, as "There is an inherent uncertainty between design and its realization in practice, since practice is not the result of design but rather a response to it." (Wenger, 1998:233).

\section{Conclusions and recommendation}

The LMS offers possibilities for changing and developing new methods in education as well as facilitating flexibility for institutions. For example, many courses can be offered off campus, and students may study courses given at different universities. Other advantages with the LMS are the tools for student communication and interaction. These possibilities are strong arguments in favour of the implementation of LMS in higher education, but they do not necessarily lessen the workloads of the staff. This means that for these tools educational benefits are larger than the benefits for lecturers in terms of time saving. On the other hand, there are a number of tools in a LMS for handling documents and information, something that may save lecturers a lot of time and effort, without making any substantial change in teaching processes. 
Most teachers with access to a LMS have chosen only to use limited parts of the system. By far the most common use is the distribution of documents to students, which teachers find efficient compared with handling paper copies, and student access to documents is better. Among lecturers there is a strong belief that the LMS can facilitate their work considerably, but they have doubts about the effects on teaching processes and student performance. It seems that when teachers decide for themselves how to use a LMS, they will use primarily those tools that facilitate their own work without affecting the teaching process. To widen use of the tools in a LMS, less experienced users need education, support and encouragement.

Lecturers clearly expect the use of LMS to increase in the future, and this investigation did not support the idea that lecturers would hesitate to use them because of any fears about the complexity of the systems or undesirable effects upon education. The key factor to increase the use of LMS is people assigned to support the lecturers in their everyday work environment.

To fully exploit the possibilities that a LMS offers, other than the parts the lecturers conceive as directly timesaving, it is necessary for institutions to work actively upon training, planning and allocation of resources. To get all benefits from the system, the work must continue until the use and handling of a LMS is a routine part of each lecturer's teaching. When that is established, it will be easier for lecturers to work in with their teaching, their planning, course administration and documentation will take less effort, and all students will have easy access to course material, information and tools for communication.

Given the possible potential benefits of a LMS in educational terms and terms of time saving for teachers, this investigation indicates that institutions of higher education should make the effort and invest the necessary resources to establish LMS as a regular tool in education as well as making the use and handling of the system a natural part of the lecturers' professional competence.

\section{References}

Björck, U. (2004). Distributed problem-based learning: Studies of a pedagogical model in practice. Göteborg: Acta Universitatis Gothoburgensis.

Björck, U., Dahlin, H. \& Sundsgårdens folkhögskola (2003). Interaktion och lärprocesser: En antologi om pedagogisk it-utveckling i folkhögskolan. Helsingborg: Sundsgårdens folkhögskola.

Bongalos, Y. Q., Bulaon, D. D. R., de Celedonio, L. P., de Guzman, A. B. \& Ogarte, C. J. F. (2006). University teachers' experiences in courseware development. British Journal of Educational Technology, 37, 695-704. 
Britain, S. \& Liber, O. (1999). A framework for pedagogical evaluation of virtual learning environments (143 Reports: Research; 160 Tests/Questionnaires). United Kingdom. http: / / www.jtap.ac.uk/ reports/htm/jtap-041.html [verified 26 June 2007 at http:/ / www.leeds.ac.uk/educol/documents / 00001237.htm\}

Collis, B. \& van der Wende, M. (2002). Models of technology and change in higher education. An international comparative survey on the current and future use of ICT in education. Center for Higher Education Policy Studies. \{verified 26 June 2007] http:/ / www.utwente.nl/ cheps/documenten/ictrapport.pdf

Craig, S. \& Jassim, H. (1995). People and project management for IT. London: McGrawHill.

Davenport, T. H. (1993). Process innovation. Boston, Mass: Harvard Business School Press [for] Ernst \& Young Center for Information Technology and Strategy.

Denscombe, M. (2000). Forskningshandboken. Lund: Studentlitteratur.

Dutton, W. H., Cheong, P. \& Park, N. (2004). The social shaping of a virtual learning environment. Electronic Journal of e-Learning, 2(2), 1-12. [verified 26 June 2007] http: / / www.ejel.org/volume-2/vol2-issue1/issue1-art3.htm

Education., G. B. N. C. o. I. i. H. (1997). Higher education in the learning society / national committee of inquiry into higher education [chairman: Sir Ron Dearing]. Report of the national committee. (pp. 467p. : ill. 461 computer laser optical disk). http: / / www.leeds.ac.uk/educol/ncihe/

Flick, U. (2002). An introduction to qualitative research (2nd ed). London: Sage.

Garrote, R. (2006). The use of learning management systems in engineering education: A Swedish case study. In M. F. Christie (Ed.), Shifting perspectives in engineering education (pp. 213-226): Chalmers Strategic Effort on Learning and Teaching (C-SELT) Chalmers University of Technology. [verified 26 June 2007] http: / / www.ituniv.se/program/ckk/mc_book_2006/mc_chapter_21.pdf.

Gisselberg, M. (2002). Distanslärare och distanslärande: En antologi. Härnösand: Distum.

Holme, I. M., Solvang, B. K. \& Nilsson, B. (1991). Forskningsmetodik. Lund: Studentlitteratur.

Merriam, S. B. (1994). Fallstudien som forskningsmetod. Lund: Studentlitteratur.

Newberg, L. A., Rouse III, R. O. \& Kruper, J. A. (1994). Integrating the world-wide web and multi-user domains to support advanced network-based learning environments. Proceedings of ED-MEDIA 94 World Conference on Educational Multimedia and Hypermedia Vancouver, British Columbia, Canada. [verified 26 June 2007] http: / / www.rpi.edu/ newbel/publications / NewbergRouseKruper1994.pdf

Pedersen, J. \& Skolverket. (1998). Informationstekniken i skolan: En forskningsöversikt. Stockholm: Statens skolverk: Liber distribution.

Regeringen (1996). Regeringens proposition 1995/96:125 åtgärder för att bredda och utveckla användningen av informationsteknik. 94. 
Regeringen (1998). Regeringens skrivelse 1997/98:176: Lärandets verktyg: Nationellt program för it $i$ skolan.

Seeger, M. A. \& Åström, A. (2005). Distansutbildning via lärplattform: En överlevnadsstrategi? Uppfattningar inom sveriges naturbruksgymnasier [distance education and learning management systems: A strategy for survival? Beliefs among the agricultural colleges of Sweden]

Sigrén, P., \& Holmqvist, H. (2005). Syntes och analys av tidigare kravspecifikationer för upphandling av lms inom den svenska högskolan 2000-2004 Härnösand: Myndigheten för Sveriges nätuniversitet.

Slevin, J. (2000). The Internet and society. Cambridge: Polity.

Wan Ng, E. C. \& Gunstone, R. (2003). Science and computer-based technologies: Attitudes of secondary science teachers. Research in Science $\mathcal{E}$ Technological Education, 21(2), 243-264.

Wenger, E. (1998). Communities of practice. Cambridge: Cambridge University Press.

\author{
Ramon Garrote Jurado MSc, Lecturer and ICT Adviser \\ School of Engineering, University College of Borås \\ Postal: 50190 BORÅS, Sweden. \\ Email: ramon.garrote@hb.se Skype: ramon_garrote \\ Tomas Pettersson $M A, M S c$ \\ Library and Information Science, University College of Borås \\ Postal: 50190 BORÅS, Sweden. Email: tomas.pettersson@hb.se
}

